\title{
Influence of agricultural utilization of sludge and compost from rural wastewater treatment plant on nitrogen passes in light soil
}

\author{
Franciszek Czyżyk, Agnieszka Rajmund* \\ Institute of Technology and Life Sciences - Lower Silesia Research Centre in Wroctaw, ul. Gen. Z. Berlinga 7, 51-209 Wroctaw \\ "Corresponding authors: e-mail: agnieszka_rajmund@o2.pl
}

\begin{abstract}
This paper presents the results of studies which aim was to determine the pollution of the water environment for both methods of preparation for the utilization of sewage sludge in agriculture. The study was conducted in 2008-2012 in lysimeters filled with light sandy soil (clayey sand). During the study variants with equal doses of nitrogen in an amount of $20 \mathrm{~g} \cdot \mathrm{m}^{-2}$ (15.7 g per one lysimeter) were supplied to the soil in sewage sludge and in the compost made from the same sludge. These variants were used three times for two species of perennial plants: Miscanthus gigantenus i Sida hermaphrodita Rusby. In a variant of sludge soil fertilizing, it was leached into water environment more than $12 \%$ of the applied nitrogen over 5 years of research. In case of compost nitrogen leaching was reduced to $8.1-10.0 \%$ of the quantity supplied to the soil.
\end{abstract}

Keywords: compost, sewage sludge, water pollution with nitrogen.

\section{INTRODUCTION}

Sludge produced in municipal wastewater treatment plants are noxious and hazardous waste to the water environment. Therefore, should be disposed and utilized with a minimal risk to the environment cleanness. One way of sewage sludge utilization is agriculture soil fertilization. Most suitable are sludge from rural areas and small non-industrialized towns. Unlike sewage waste in large cities, they do not contain excessive levels of heavy metals and generally meet the existing legislation requirements. Wastewater sludge has a high fertilizer and soil-forming value $e^{1,2,3,4,5}$.

One method of sewage sludge preparation for agriculture use is composting $\mathbf{6}, \mathbf{7}, \mathbf{8 , 9 , 1 0}$. Composting of sludge is a long-term process and requires proper equipment, space and effort. For economic reasons, hygienisation of sludge with calcium oxide (II) $(\mathrm{CaO})$ is often used with its direct application to the soil.

Application of sewage sludge to fertilize the soil, regardless of their previous treatment creates hazard of penetration of some components (especially nitrogen) into the water environment. Nitrogen in the sludge and composts occurs mainly in an organic form and its mineral form are from several to more than $20 \%$ of the total nitrogen content ${ }^{11,12}$. Organic nitrogen supplied to the soil undergoes a complex and dynamic changes ${ }^{\mathbf{1 3}, 14}$. As a result of these changes, especially nitrification process, mineral forms of nitrogen in particular nitrates (V) are formed. $\mathrm{N}_{-} \mathrm{NO}_{3}{ }^{-}$and $\mathrm{N}-\mathrm{NH}_{4}{ }^{+}$released during the mineralization process are taken up by plants, although much of it passes into the groundwater ${ }^{\mathbf{1 5}, 16}$. The amount of nitrogen leaching into the water environment depends among others on the form of the fertilizer used and the size of the dose. It may even be more than $60 \mathrm{~kg}$ $\mathrm{N} \cdot \mathrm{ha}^{-1}$ per year ${ }^{17}$.

Sewage sludge composts are characterized by a high content of humificated organic matter. Humus is the predominating sewage sludge component that only after the introduction into the soil undergo biochemical mineralization and humification processes ${ }^{\mathbf{1 8}}$. The pace and products of these changes are dependent on climatic and soil conditions (air, water and $\mathrm{pH})^{\mathbf{1 9}}$. This gives a reason to believe that especially nitrogen contamination of water environment will vary. It will depend on whether the sewage sludge or compost produced out of it is provided to the soil. There are no data in the literature on the results of comparative studies carried out in the same conditions, using both forms of sludge and their impact on the water environment and soil.

This work presents the results of the studies whose aim was to determine the pollution of the water environment for both methods of preparation for the utilization of sewage sludge in agriculture

\section{EXPERIMENTAL SECTION}

The study was conducted in 2008-2012 in lysimeters filled with light sandy soil (clayey sand), an average of $14 \%$ of the earthy particles (fraction $<0.02 \mathrm{~mm}$ ). The conditions in the lysimeters are similar to the natural field conditions. Lysimeters with a diameter of $100 \mathrm{~cm}$ and a depth of $130 \mathrm{~cm}$ are completely submerged in the ground and is surrounded by agricultural fields. The study was conducted at the Research Station in Kamieniec belonging to the Lower Silesia Wroclaw Research Centre.

In subsequent years of the studies the stabilized and mechanically dehydrated sludge from the rural mechanical-biological wastewater treatment plant was used as well as the compost produced from this sludge and waste plant.

During the study variants with equal doses of nitrogen in an amount of $20 \mathrm{~g} \cdot \mathrm{m}^{-2}$ (15.7 $\mathrm{g}$ per one lysimeter) were supplied to the soil in sewage sludge and in the compost made from the same sludge. These variants were used three times for two species of perennial plants:

- Miscanthus gigantenus,

- Sida hermaphrodita Rusby.

These are the plants with a high demand for nutrients (especially nitrogen), normally grown for biomass as a renewable source of energy (energy crops). For both plants, high doses of nitrogen equivalent to $200 \mathrm{~kg}$ $\mathrm{N} \cdot \mathrm{ha}^{-1}$, were used.

During the study period amounts of precipitation and leachate from the lysimeters were measured. Chemical composition analyzes of the sewage sludge, compost, 
rainwater and leachate were performed with currently valid and the most commonly used methods ${ }^{20,21}$. The concentration of nitrogen and its forms in leachates was marked by the colorimetric indophenol method according to $^{22}$, using the UV-Vis 916 GBC spectrophotometer. The following analyses were made for the studied sludge and compost: loss on ignition by gravimetric method according $\mathrm{to}^{23}$, organic carbon - made by Tiurin method, involving wet oxidation of organic matter, followed by potassium dichromate $-\mathrm{K}_{2} \mathrm{Cr}_{2} \mathrm{O}_{7}$ treatment. The remaining in the $\mathrm{K}_{2} \mathrm{Cr}_{2} \mathrm{O}_{7}$ solution, was titrated with Mohr's salt. The concentration of nitrogen and its forms in an aqueous extract was determined by the colorimetric indophenol method according to ${ }^{22}$.

The results of leachate from lysimeters and the concentration of nitrogen forms were statistically analyzed taking into account the long-term average. The statistical calculations were made in the Statistica $10 \mathrm{PL}$. The T-test was made for independent samples at variable at level of significance $p<0.05$. In addition, the coefficient of variation of the concentrations of nitrogen and its forms in leachates was calculated. The results are summarized in the tables.

\section{RESULTS AND DISCUSSION}

Chemical analysis of the sewage sludge used in the studies revealed that it contained $45.0-65.9 \mathrm{mg} \cdot \mathrm{g}^{-1} \cdot \mathrm{DM}$ (average $53.3 \mathrm{mg} \cdot \mathrm{g}^{-1} \cdot \mathrm{DM}$ ) of total nitrogen, and $64.1-76.4 \%$ (average $71 \%$ ) of organic matter (Table 1). Compost prepared from the sewage sludge and waste plant contained about 2 times less nitrogen 21.9-28,4 $\mathrm{mg} \cdot \mathrm{g}^{-1} \cdot \mathrm{DM}$ (average $25.0 \mathrm{mg} \cdot \mathrm{g}^{-1} \cdot \mathrm{DM}$ ) and less organic matter (average 62\%). Differences in nitrogen and its forms in the sludge and compost were confirmed statistically.

In order to provide an equal dose of nitrogen to the soil in both fertilization methods, greater amount of compost than sewage sludge was used. Therefore, the amount of organic matter supplied to the soil with compost was greater than the amount supplied with sewage sludge. This could have an impact on the reduction of leaching from soil when fertilized with compost. Leachates from the soil depends mainly on the amount of rainfall and the transpiration of plants during the growing season as well as the type of soil and its organic matter content.

Individual years of study differed considerably in terms of the amount of rainfall (Table 2). The volume of leachate from the lysimeters also varied (Table 3). Leachate occurred primarily during late autumn and winter periods. During plants growing periods the volume of leachates was much smaller and they occurred only after heavy rainfall.

The leachates volume in the case when soil was fertilized with sewage sludge was higher than in the case when it was fertilized with compost. It is due to the fact that the soil added to the compost improves its properties faster, and increases water holding capacity of the soil $^{24,25,26}$. While the sludge added to the soil is under the biochemical mineralization and humification processes. The differences in the volume of leachate from the soil fertilized with sewage sludge and compost, although it is significant, have been statistically confirmed only in the variant of the Sida hermaphrodita Rusby species. This shows the difference of the transpiration of the used plant species. It has occurred in all years of the study and in both plant species. A substantial effect of plant transpiration on the volume of leachates has also been

Table 1. The nitrogen content and its forms, and carbon

\begin{tabular}{|c|c|c|c|c|c|c|c|c|}
\hline \multirow{2}{*}{ Year } & \multirow{2}{*}{ Fertilizer } & \multicolumn{5}{|c|}{ Component in $\mathrm{mg} \cdot \mathrm{g}^{-1} \cdot \mathrm{DM}$} & \multirow{2}{*}{$\begin{array}{c}\begin{array}{c}\text { Organic } \\
\text { matter }\end{array} \\
\% \\
\end{array}$} & \multirow{2}{*}{$\mathrm{C}: \mathrm{N}$} \\
\hline & & $\mathrm{N}_{\text {Tot }}$ & $\mathrm{N}_{\text {org }}$ & $\mathrm{N}-\mathrm{NOx}$ & $\mathrm{N}-\mathrm{NH}_{3}$ & $\mathrm{C}_{\text {org }}$ & & \\
\hline \multirow{2}{*}{2008} & Sewage sludge & 52.2 & 47.4 & 0.53 & 4.26 & 307.3 & 76 & 6 \\
\hline & Compost & 27.3 & 26.4 & 0.59 & 0.26 & 310.4 & 66 & 12 \\
\hline \multirow{2}{*}{2009} & Sewage sludge & 53.3 & 48.6 & 0.13 & 4.51 & 297.3 & 70 & 6 \\
\hline & Compost & 24.8 & 23.4 & 0.81 & 0.55 & 292.8 & 59 & 12 \\
\hline \multirow{2}{*}{2010} & Sewage sludge & 65.9 & 64.5 & 0.23 & 1.14 & 311.4 & 72 & 5 \\
\hline & Compost & 22.8 & 22.2 & 0.29 & 0.29 & 258.6 & 66 & 11 \\
\hline \multirow{2}{*}{2011} & Sewage sludge & 50.0 & 47.6 & 0.24 & 2.20 & 328.5 & 71 & 7 \\
\hline & Compost & 21.9 & 19.8 & 1.84 & 0.23 & 245.4 & 53 & 11 \\
\hline \multirow{2}{*}{2012} & Sewage sludge & 45.0 & 41.8 & 0.32 & 2.84 & 255.1 & 64 & 6 \\
\hline & Compost & 28.4 & 27.1 & 1.05 & 0.30 & 266.8 & 64 & 9 \\
\hline \multirow{2}{*}{$\begin{array}{l}\text { Avg } \pm S . D . \\
\text { of } 5 \text { years }\end{array}$} & Sewage sludge & $53.3 \pm 7.7$ & $50.0 \pm 8.5$ & $0.29 \pm 0.15$ & $2.99 \pm 1.41$ & $299.9 \pm 27.5$ & $71 \pm 4.3$ & $6 \pm 0.7$ \\
\hline & Compost & $25.0 \pm 2.80$ & $23.8 \pm 3.02$ & $0.92 \pm 0.59$ & $0.33 \pm 0.13$ & $274.8 \pm 26.4$ & $62 \pm 4.3$ & $11 \pm 1.2$ \\
\hline Test $-\mathrm{t}$ & $\begin{array}{l}\text { Sewage sludge } \\
\text { vs. Compost }\end{array}$ & $0.00006^{*}$ & $0.00019^{*}$ & $0.04984^{*}$ & $0.00301^{*}$ & 0.17845 & $0.02170^{*}$ & $0.00005^{*}$ \\
\hline
\end{tabular}

Explanations: *statistically significant at the level of $(p<0.05)$, Avg- average; S.D.-standard deviation

Source: own studies.

Table 2. Atmospheric precipitation at research station of the Lower Silesian Research Centre in Kamieniec Wrocławski in the years 2008-2012

\begin{tabular}{|c|c|c|c|c|c|c|c|c|c|c|c|c|c|c|}
\hline \multirow[b]{2}{*}{ Year } & \multicolumn{12}{|c|}{ Precipitation in months [mm] } & \multirow{2}{*}{$\begin{array}{l}{ }^{*} \text { Period } \\
\text { IV-X } \\
{[\mathrm{mm}]}\end{array}$} & \multirow{2}{*}{$\begin{array}{c}\text { **Period } \\
\text { XI-III } \\
{[\mathrm{mm}]}\end{array}$} \\
\hline & I & II & III & IV & V & $\mathrm{VI}$ & VII & VIII & IX & $X$ & $X I$ & XII & & \\
\hline 2008 & 61.7 & 12.2 & 43.8 & 82.5 & 35.0 & 45.7 & 50.2 & 103.6 & 28.8 & 42.2 & 29.2 & 16.8 & 345.8 & 205.9 \\
\hline 2009 & 38.2 & 56.7 & 58.2 & 30.1 & 85.8 & 174.1 & 138.8 & 58.3 & 11.9 & 87.3 & 32.5 & 58.5 & 499.0 & 331.4 \\
\hline 2010 & 47.8 & 10.3 & 37.0 & 60.5 & 169.2 & 42.5 & 97.3 & 129.7 & 132.2 & 5.0 & 73.5 & 67.0 & 631.4 & 240.6 \\
\hline 2011 & 34.8 & 11.0 & 48.8 & 30.7 & 51.1 & 84.2 & 143.1 & 79.1 & 36.6 & 46.2 & 0.5 & 50.8 & 424.8 & 192.1 \\
\hline 2012 & 59.5 & 38.9 & 12.3 & 27.8 & 66.2 & 106.8 & 100.2 & 72.6 & 56.9 & 43.7 & 32.1 & 24.6 & 430.5 & 211.1 \\
\hline
\end{tabular}

*Period of vegetation of plants (IV-X), ${ }^{* *}$ Period outside the vegetation of plants (XI-III).

Source: own studies 
Table 3. Annual amount of precipitation and volume of leachates from particular fertilization variants in the period of $2008-2012$

\begin{tabular}{|c|c|c|c|c|c|}
\hline \multirow{4}{*}{ Year } & \multirow{3}{*}{$\begin{array}{l}\text { Annual amount } \\
\text { of precipitation }\end{array}$} & \multirow{2}{*}{\multicolumn{2}{|c|}{$\begin{array}{l}\text { Volume of leachates from particular variants } \\
\text { (Miscanthus gigantenus) }\end{array}$}} & \multirow{2}{*}{\multicolumn{2}{|c|}{$\begin{array}{l}\text { Volume of leachates from particular variants } \\
\text { (Sida hermaphrodita Rusby) }\end{array}$}} \\
\hline & & & & & \\
\hline & & Sewage sludge & Compost & Sewage sludge & Compost \\
\hline & $\mathrm{mm}$ & $\mathrm{dm}^{3}$ & $\mathrm{dm}^{3}$ & $\mathrm{dm}^{3}$ & $\mathrm{dm}^{3}$ \\
\hline 2008 & 551.7 & 262 & 213 & 262 & 155 \\
\hline 2009 & 830.4 & 186 & 169 & 158 & 124 \\
\hline 2010 & 872.0 & 202 & 162 & 165 & 111 \\
\hline 2011 & 616.9 & 63 & 41 & 49 & 26 \\
\hline 2012 & 641.6 & 139 & 118 & 107 & 74 \\
\hline Test $-\mathrm{t}$ & - & \multicolumn{2}{|c|}{0.3841} & \multicolumn{2}{|c|}{$0.0475^{*}$} \\
\hline
\end{tabular}

Explanations: *statistically significant at the level of $(p<0.05)$.

Source: own studies.

noticed. In the first year of the study (2008), when plants were just planted and still poorly developed, leachates in both variants of fertilization were most abundant, despite smallest precipitation this year.

Average concentrations of total nitrogen and its forms in leachates from lysimeters were similar in both variants of fertilization (Table 4). Differences in the content (concentration) of nitrogen in the leachate from soil fertilized with sewage sludge and compost have not been statistically confirmed (with the exception of differences in the concentrations of N-NOx variation of species Sida hermaphrodita Rusby). These concentrations were calculated as the weighted average of the volume of sludge and the contents of analyzed components. In the first year of the study, with a poorly developed plant the sludge contained large amounts of nitrate nitrogen. In the following years, when the plants were in full development, organic nitrogen was predominant in both fertilization variants. This demonstrates the extensive collection of $\mathrm{N}^{-\mathrm{NO}_{\mathrm{x}}}$ by plants and leaching of nitrogen in water-soluble organic compounds contained in the sludge and in compost. Organic nitrogen is not absorbed by plants ${ }^{27}$.
The leachate test revealed very high variability of nitrate nitrogen concentrations in both variants of fertilization (Table 5).

In the leachate from lysimeters planted with miscanthus concentration the changeability of this form of nitrogen exceeded $200 \%$. This was probably due to the variable collecting of this form of nitrogen by plants throughout the year and due to the impact of temperature on the nitrification process of organic nitrogen contained in sewage sludge and compost. The changeability of the concentration of total nitrogen, as well as of other forms was much smaller and not more than $100 \%$.

Variability and seasonality of nitrate concentrations in the leachate from the soil were also shown by the studies in the facilities used for agriculture ${ }^{28}$. Maximum concentrations of nitrate were noticed at the turn of February and March, before the start of plant vegetation. The research conducted in the UK confirmed high variability of nitrate and its maximum values occurrence during the early spring ${ }^{29}$.

The quantity (volume) of the nitrogen in the soil is a much more important parameter than the concentration. Is influenced by various factors. One of the most important is the way of soil usage and maintenance of agricultural production ${ }^{30,31}$. Crucial impact on the

Table 4. The average annual concentration of total nitrogen and its forms in the leachate from different variants of fertilization during 2008-2012 in $\mathrm{mg} \cdot \mathrm{dm}^{-3}$

\begin{tabular}{|c|c|c|c|c|c|c|c|}
\hline \multirow{2}{*}{ Variant } & \multirow{2}{*}{ Component } & \multicolumn{5}{|c|}{ Year } & \multirow{2}{*}{$\begin{array}{l}\text { Avg } \pm \text { S.D. } \\
\text { for } 5 \text { yers }\end{array}$} \\
\hline & & 2008 & 2009 & 2010 & 2011 & 2012 & \\
\hline \multirow{4}{*}{$\begin{array}{c}\text { Sewage sludge } \\
\text { (Miscanthus gigantenus) }\end{array}$} & $\mathrm{N}_{\text {tot }}$ & 27.7 & 6.1 & 7.4 & 5.1 & 8.6 & $9.6 \pm 8.7$ \\
\hline & $\mathrm{N}_{\text {org }}$ & 5.0 & 5.3 & 7.1 & 4.6 & 3.7 & $5.1 \pm 2.4$ \\
\hline & $\mathrm{N}-\mathrm{NO}_{\mathrm{x}}$ & 22.3 & 0.5 & 0.1 & 0.2 & 4.7 & $4.2 \pm 8.7$ \\
\hline & $\mathrm{N}-\mathrm{NH}_{3}$ & 0.4 & 0.4 & 0.2 & 0.3 & 0.2 & $0.3 \pm 0.1$ \\
\hline \multirow{4}{*}{$\begin{array}{c}\text { Compost } \\
\text { (Miscanthus gigantenus) }\end{array}$} & $\mathrm{N}_{\text {Tot }}$ & 28.9 & 6.7 & 8.5 & 5.4 & 5.1 & $10.1 \pm 9.3$ \\
\hline & $\mathrm{N}_{\text {org }}$ & 5.1 & 5.7 & 7.9 & 5.0 & 3.9 & $5.7 \pm 2.9$ \\
\hline & $\mathrm{N}-\mathrm{NO}_{\mathrm{x}}$ & 23.4 & 0.6 & 0.2 & 0.2 & 0.9 & $4.1 \pm 9.1$ \\
\hline & $\mathrm{N}-\mathrm{NH}_{3}$ & 0.3 & 0.4 & 0.3 & 0.3 & 0.2 & $0.3 \pm 0.1$ \\
\hline \multirow{4}{*}{$\begin{array}{l}\text { Sewage sludge vs. Compost } \\
\text { (Miscanthus gigantenus) }\end{array}$} & $\mathrm{N}_{\text {tot }}$ & \multicolumn{6}{|c|}{0.7780} \\
\hline & $\mathrm{N}_{\text {org }}$ & \multicolumn{6}{|c|}{0.2908} \\
\hline & $\mathrm{N}-\mathrm{NO}_{\mathrm{x}}$ & \multicolumn{6}{|c|}{0.9524} \\
\hline & $\mathrm{N}-\mathrm{NH}_{3}$ & \multicolumn{6}{|c|}{0.0857} \\
\hline \multirow{4}{*}{$\begin{array}{c}\text { Sewage sludge } \\
\text { (Sida hermaphrodita Rusby) }\end{array}$} & $\mathrm{N}_{\text {tot }}$ & 27.4 & 7.7 & 10.4 & 8.7 & 9.5 & $12.1 \pm 8.3$ \\
\hline & $\mathrm{N}_{\text {org }}$ & 2.5 & 4.6 & 7.4 & 4.3 & 3.5 & $4.7 \pm 2.7$ \\
\hline & $\mathrm{N}-\mathrm{NO}_{\mathrm{x}}$ & 24.4 & 2.7 & 2.8 & 4.2 & 5.9 & $7.1 \pm 9.1$ \\
\hline & $\mathrm{N}-\mathrm{NH}_{3}$ & 0.5 & 0.3 & 0.2 & 0.2 & 0.1 & $0.3 \pm 0.2$ \\
\hline \multirow{4}{*}{$\begin{array}{c}\text { Compost } \\
\text { (Sida hermaphrodita Rusby) }\end{array}$} & $\mathrm{N}_{\text {tot }}$ & 28.1 & 8.2 & 10 & 8.5 & 13.7 & $12.9 \pm 8.3$ \\
\hline & $\mathrm{N}_{\text {org }}$ & 3.2 & 3.9 & 7.7 & 4.7 & 3.2 & $4.7 \pm 2.4$ \\
\hline & $\mathrm{N}-\mathrm{NO}_{\mathrm{x}}$ & 24.3 & 4.0 & 2.0 & 3.5 & 10.4 & $7.9 \pm 9.1$ \\
\hline & $\mathrm{N}-\mathrm{NH}_{3}$ & 0.6 & 0.3 & 0.3 & 0.2 & 0.1 & $0.3 \pm 0.2$ \\
\hline \multirow{4}{*}{$\begin{array}{l}\text { Sewage sludge vs. Compost } \\
\text { (Sida hermaphrodita Rusby) }\end{array}$} & $\mathrm{N}_{\text {tot }}$ & \multicolumn{6}{|c|}{0.6806} \\
\hline & $\mathrm{N}_{\text {org }}$ & \multicolumn{6}{|c|}{0.9739} \\
\hline & $\mathrm{N}-\mathrm{NO}_{\mathrm{x}}$ & \multicolumn{6}{|c|}{$0.0097^{*}$} \\
\hline & $\mathrm{N}-\mathrm{NH}_{3}$ & \multicolumn{6}{|c|}{0.9347} \\
\hline
\end{tabular}


Table 5. Average concentration and the variability coefficient of total nitrogen and its forms in the leachates samples collected in 2008-2012 $\left(\mathrm{mg} \cdot \mathrm{dm}^{-3}\right)$

\begin{tabular}{|c|c|c|c|c|c|}
\hline \multirow{2}{*}{ Variant } & \multirow{2}{*}{$\frac{x}{\min -\max }$} & \multicolumn{4}{|c|}{ Component } \\
\hline & & $\mathrm{N}_{\text {tot }}$ & $N_{\text {org }}$ & $\mathrm{N}-\mathrm{NO}_{x}$ & $\mathrm{~N}-\mathrm{NH}_{3}$ \\
\hline \multirow{3}{*}{$\begin{array}{c}\text { Sewage sludge } \\
\text { (Miscanthus gigantenus) } \\
n=44\end{array}$} & $x$ & 9.9 & 5.1 & 4.5 & 0.3 \\
\hline & $\overline{\min -\max }$ & $3.0-40.6$ & $2.5-10.8$ & $\overline{0.1-34.4}$ & $0.1-0.7$ \\
\hline & V\% & 88 & 47 & 192 & 46 \\
\hline \multirow{3}{*}{$\begin{array}{c}\text { Compost } \\
\text { (Miscanthus gigantenus) } \\
\mathrm{n}=46\end{array}$} & $x$ & 9.8 & 5.5 & 4.0 & 0.3 \\
\hline & $\overline{\min -\max }$ & $\overline{2.4-40.6}$ & $\overline{1.9-13.3}$ & $\overline{0.1-35.1}$ & $0.1-0.7$ \\
\hline & $\mathrm{V} \%$ & 92 & 47 & 220 & 38 \\
\hline \multirow{3}{*}{$\begin{array}{c}\text { Sewage sludge (Sida } \\
\text { hermaphoidta Rusby) } \\
\qquad \mathrm{n}=40\end{array}$} & $x$ & 12.3 & 4.8 & 7.3 & 0.3 \\
\hline & $\min -\max$ & $3.7-34.8$ & $1.2-10.8$ & $0.3-32.7$ & $0.1-1.0$ \\
\hline & $\vee \%$ & 66 & 57 & 120 & 77 \\
\hline \multirow{3}{*}{$\begin{array}{c}\text { Compost (Sida hermaphoidta } \\
\text { Rusby) } \\
\mathrm{n}=42\end{array}$} & $x$ & 13.1 & 4.7 & 8.0 & 0.3 \\
\hline & $\overline{\min -\max }$ & $\overline{4.0-37.0}$ & $\overline{1.6-10.9}$ & $\overline{0.6-33.3}$ & $\overline{0.1-1.1}$ \\
\hline & V\% & 62 & 49 & 110 & 69 \\
\hline
\end{tabular}

Explanations: $\mathrm{n}$ - numer of sample, $\mathrm{x}$ - average concentration, $\mathrm{V} \%$ - variability coefficient. Source: own studies.

amount of nitrogen discharged in the leachate from the soil has the size of the dose and the type (form) of used fertilizer. This has been inter alia shown by studies with using identical doses of nitrogen supplied in ammonium sulphate and composts. Nitrate concentrations and the amount of discharged nitrogen in the leachate in the fertilization of the soil with ammonium sulphate were much higher than with the same dose of nitrogen in the $\operatorname{compost}^{27}, 32,33$. The greater fertilization dose the greater was the difference in the losses of applied nitrogen within fertilizer types. In the soil fertilized with sewage sludge and compost the amount of nitrogen discharged from the leachate was little differentiated (Table 6). The differences are statistically confirmed only in the variant of the Sida hermaphrodita Rusby species.

The amount of the total nitrogen discharged in the leachate (per $1 \mathrm{~m}^{2}$ ) and its concentration decrease, throughout the study period (Table 6). Strong influence of plants on nitrogen losses noted, due to its leaching from the soil. In the first year after planting, when they have extracted a little of both the water and nutrients, nitrogen losses were very large (tens of percent). In the following years, under the full development of plants, these losses declined repeatedly.

Table 7 shows the overall amount of nitrogen supplied to the soil in the sewage sludge, compost and precipitation as well as leachate discharged. The amount of nitrogen provided to the soil from rainfall in the research area was $3.9 \mathrm{~g} \cdot \mathrm{m}^{-2}$. It was calculated on the basis of precipitation and the weighted average concentration of total nitrogen in the rain. It was a slightly greater amount as in previous years in this area, which was $3.4-3,7 \mathrm{~g} \cdot \mathrm{m}^{-2} 34$.

The results given in Tables 6 and 7 clearly show the difference between the amount of nitrogen leaching from the soil in sewage sludge and compost fertilization variants. In a variant of sludge soil fertilizing, it was leached into water environment more than $12 \%$ of the applied nitrogen over 5 years of research. In the case

Table 6. Amounts of total nitrogen drained from leachate during the period of 2008-2012

\begin{tabular}{|l|r|r|r|r|}
\hline \multirow{2}{*}{ Year } & \multicolumn{4}{|c|}{ Amount of total nitrogen leaching from different variants of fertilization. $\mathrm{mg} \cdot \mathrm{m}^{-2}$} \\
\cline { 2 - 5 } & \multicolumn{2}{|c|}{ Miscanthus gigantenus } & Sida hermaphrodita Rusby & Compost \\
\cline { 2 - 5 } & Sewage sludge & Compost & 9145 & 5548 \\
\hline 2008 & 9245 & 7842 & 1550 & 1295 \\
\hline 2009 & 1445 & 1442 & 2186 & 1414 \\
\hline 2010 & 1904 & 2854 & 543 & 1291 \\
\hline 2011 & 409 & 767 & 1295 & 9831 \\
\hline 2012 & 1523 & 12087 & 14719 & $0.0475^{*}$ \\
\hline$\Sigma$ & 14527 & & & \\
\hline
\end{tabular}

*Statistically significant at the level of $(p<0.05)$. Source: own studies.

Table 7. Amounts of nitrogen and phosphorus supplied to the soil and drained from leachate during the period of 2008-2012 in $\mathrm{g} \cdot \mathrm{m}^{-2}$

\begin{tabular}{|c|c|c|c|c|c|}
\hline \multirow{2}{*}{ Variants of fertilization } & \multicolumn{3}{|c|}{ Amounts of $\mathrm{N}_{\text {tot }}$ supplied $\mathrm{g} \cdot \mathrm{m}^{-2}$} & \multicolumn{2}{|c|}{$\begin{array}{l}\text { Amounts of } \mathrm{N}_{\text {tot }} \text { drained } \\
\text { from leachate }\end{array}$} \\
\hline & in fertilizers & of precipitation & $\Sigma$ & $\mathrm{g} \cdot \mathrm{m}^{-2}$ & $\%$ \\
\hline $\begin{array}{l}\text { Sewage sludge: } \\
\text { Miscanthus gigantenus } \\
\text { Sida hermaphoidta Rusby }\end{array}$ & $\begin{array}{l}100 \\
100\end{array}$ & $\begin{array}{l}19.5 \\
19.5\end{array}$ & $\begin{array}{l}119.5 \\
119.5\end{array}$ & $\begin{array}{l}14.5 \\
14.7\end{array}$ & $\begin{array}{l}12.1 \\
12.3\end{array}$ \\
\hline $\begin{array}{l}\text { Compost: } \\
\text { Miscanthus gigantenus } \\
\text { Sida hermaphoidta Rusby }\end{array}$ & $\begin{array}{l}100 \\
100 \\
\end{array}$ & $\begin{array}{l}19.5 \\
19.5 \\
\end{array}$ & $\begin{array}{l}119.5 \\
119.5 \\
\end{array}$ & $\begin{array}{r}12.1 \\
9.8\end{array}$ & $\begin{array}{r}10.1 \\
8.2 \\
\end{array}$ \\
\hline
\end{tabular}

Source: own studies. 
of compost nitrogen leaching was reduced to $8.2-10.1 \%$ of the quantity supplied to the soil. There were smaller nitrogen losses than in the case of compost fertilizer, where the loss of only mineral nitrogen exceeded $12 \%$, and in the conditions of using mineral fertilizers it was about $28 \%$ of the applied nitrogen doses ${ }^{17}$.

\section{CONCLUSION}

Compost made from sewage sludge and waste plants contains about two times less nitrogen and slightly less organic matter than the sludge.

The volume of soil sludge depends, not only on the amount of precipitation, but also on the variant of fertilization. In the variants of soil fertilization with compost leachate the volume was much smaller than in the case of sewage sludge fertilizer in the same soil and climatic conditions.

Nitrogen pollution of the water environment is lower when using compost rather than sewage sludge soil fertilization. In the case of identical doses of nitrogen, introduced into the sandy soil in the compost and sewage sludge, increased leaching of this component was observed in sewage sludge fertilization variant (over $12 \%)$ than compost $(8.2-10.1 \%)$.

There is a leaching of not only the mineral forms of nitrogen, but also organic nitrogen $(30-50 \%$ of the total leaching amount) from the soil fertilized with sewage sludge and compost.

\section{LITERATURE CITED}

1. Baran, S., Flis-Bujak, M., Turski, R. \& Żukowska, G. (1993). Transformation of organic matter in the sandy soil fertilized with sewage sludge. Zesz. Probl. Post. Nauk Rol. 409, 243-250 (in Polish).

2. Krzywy, E., Wołoszyk, C. \& Iżewska, A. (2000). Evaluation of the possibility of the land application of sludge compost from municipal wastewater treatment plants. Charakterystyka i zagospodarowanie osadów ściekowych, Bydg. Tow. Ściek. Seria A 30, 63-83 (in Polish).

3. Loveland, P. \& Webb, J. (2003). Is there a critical level of organic matter in the agricultural soils of temperate regions: a review. Soil Till. Res. 70, 1-18. DOI: dx.doi.org/10.1016/ S0167-1987(02)00139-3.

4. Wei, Y. \& Liu, Y. (2005). Effects of sewage sludge compost application on crops and cropland in a 3-year field study Chemosphere, 59, pp. 1257-1265.

5. Song, U. \& Lee, E.J. (2010). Environmental and economical assessment of sewage sludge compost application on soil and plants in a landfill. Resources, Conservation and Recycling, 54(12), 1109-1116.

6. Böhem, L. (1957). Compostierung von Klarschlamm nach dem Verfahren natürlicher compostierung, Landvirtschaft $\mathrm{H}$ 12, pp. 1-83.

7. Bernal, P., Navarro, A.F., Roig, A., Cegarra, J. \& Garcia, D. (1996). Carbon and nitrogen transformation during composting of sweet sorghum bagasse Biology and Fertility of Soils, 22, pp. 141-148.

8. Czyżyk, F., Kuczewska, M. \& Sieradzki, T. (2001). Preliminary results of studies composting liquid sewage sludge with straw. Zesz. Probl. Post. Nauk Rol. 475, 263-270 (in Polish).

9. Iżewska, A., Krzywy, E., Balcer, K. (2007). Impact of sewage sludge and composts prepared from sewage sludge on the content and uptake of macronutrients by straw of miscanthus sacchariflorus. Pol. J. Chem. Tech. 9(3), 56-59. DOI: 10.2478/ v10026-007-0054-3. (in Polish).
10. Siuta, J., Wasiak, G., Chłopecki, K., Kazimierczuk, M., Jońca, M., Mamelka, D. \& Sułek, S. (1996). Natural and technical processing of sewage sludge into compost. Warszawa IOŚ 40 (in Polish).

11. Czyżyk, F. \& Kozdraś, M. (2004). Chemical properties and composting of sludge from rural sewage wastewater treatment plant. Woda Środowisko Obszary Wiejskie, 4, 2a (11), 559-569 (in Polish).

12. Krzywy, J., Krzywy, E., Krzywy-Gawrońska, E. \& Rozmarynowska, M. (2007). The effect of sewage sludge composts and potato pulp on uptaking of macroelements by the grain and straw of the spring triticale. Pol. J. Chem. Tech.9(4), 14-17. DOI: 10.2478/v10026-007-0081-0.

13. Fotyma, E. (1996). Application of the method $\mathrm{N}_{\min }$ to assess the environmental effects of nitrogen fertilization. Zesz. Probl. Post. Nauk Rol. 440, 89-99. (in Polish).

14. Scholefield, D., Lockyer, D.R., Whitehead, D.C. \& Tyson, K.C. (1991). A model to predict transformations and losses of nitrogen in UK pastures grazed by beaf cattle. Plant and Soil. 132(2), 165-171. DOI: 10.1007/BF00010397.

15. Gotkiewicz, J. (1996). The release and transformation of mineral nitrogen in soils hydrogenic. Zesz. Probl. Post. Nauk Rol. 440, 121-129. (in Polish).

16. Sapek, B. (1996). Potential leaching of nitrates on dynamic background of nitrogen mineralization in grassland soils. Zesz. Probl. Post. Nauk Rol. 440, 331-341. (in Polish).

17. Czyżyk, F., Pulikowski, K., Strzelczyk, M. \& Pawęska, K. (2011). Outflow of mineral forms of nitrogen from a light soil fertilised every year with compost from sewage sludge and mineral fertilisers. Woda Środowisko Obszary Wiejskie 11 4 (36), 95-105 (in Polish).

18. Doublet, J., Francou, C., Pétraud, J.P., Dignac, M.F., Poitrenaud, M. \& Houot, S. (2010). Distribution of C and N mineralization of a sludge compost within particle-size fractions. Biores. Tech. 101(4), 1254-1262. DOI: dx.doi.org/10.1016/j. biortech.2009.09.037.

19. Busby, R.R., Torberth, H.A. \& Gebhart, D.L. (2007). Carbon and nitrogen mineralization of non-composted and composted municipal solid waste in sandy soils. Soil Biol. Biochem. 39, 1277-1283. DOI: dx.doi.org/10.1016/j.soilbio.2006.12.003.

20. Hermanowicz, W., Dojlido, J., Dożańska, W., Koziorowska, B. \& Zerze, J. (1999). Physico-chemical analysis of water and wastewater. Arkady. (in Polish).

21. Set of standards. (1999). Water and wastewater, Wydaw. Normalizacyjne Alfa-Wero (in Polish).

22. Polish Standard PN-76/C-04576/01 Water and wastewater - Nitrogen content tests - Determination of ammonium nitrogen by the colorimetric method indophenol. (in Polish).

23. Polish Standard PN-EN 15935:2013-02E Sewage sludge, treatment of biowaste, soil and waste - determination of loss on ignition. (in Polish).

24. Vengadaramana, A., Jashothan, P.T.J. (2012). Effect of organic fertilizers on the water holding capacity of soil in different terrains of Jaffna peninsula in Sri Lanka J. Nat. Prod. Plant Resour., 2 (4), 500-503.

25. Curtis, M.J. \& Claassen, V.P. (2005). Compost incorporation increases plant available water in a drastically disturbed serpentine soil. Soil Science, 170. 939-953.

26. Nguyen, T.T., Fuentes, S. \& Marschner, P. (2012). Effects of compost on water availability and gas exchange in tomato during drought and recovery. Plant Soil and Environment, 58(11), 495-502.

27. Hartl, W., \& Erhart, E. (2005). Crop nitrogen recovery and soil nitrogen dynamics in a 10 year field experiment with biowaste compost. Journal of Plant Nutrition and Soil Science, 168(6), 781-788. DOI: 10.1002/jpln.200521702.

28. Pulikowski, K., Paluch, J., Paruch, A. \& Kostrzewa, S. (2005). The period of maximum occurrence of nitrate concentrations in surface waters. Zesz. Probl. Post. Nauk Rol., Warszawa 505 : 339-345. (in Polish). 
29. Jarvie, H.P., Withers, P.J.A., Bowes, M.J., Palmer-Felgate, E.J., Harper, D.M., Wasiak, K., Wasiak, P., Hodgkinson, R.A., Bates, A., Stoate, C., Neal, M., Wickham, H.D., Harman, S.A. \& Armstrong, L.K. (2010). Streamwater phosphorus and nitrogen across a gradient in rural-agricultural land use intensity. Agriculture, Ecosystems and Environment, 135, 238-252 DOI: 10.1016/j.agee.2009.10.002.

30. Koc, J., Solarski, K., Rochwerger, A. (2007). Effect of a land reclamation system on the volume and seasonality of nitrate runoff from croplands. J. Elementol. 12(2), 121-133.

31. Rode, M., Thiel, E., Franko, U., Wenk, G. \& Hesser, F. (2009). Impact of selected agricultural management options on the reduction of nitrogen loads in three representative meso scale catchments in Central Germany. Sci. Tot.Environ. 407, 3459-3472.

32. Maeda, M., Zhao, B., Ozaki, Y. \& Yoneyama, T. (2003). Nitrate leaching in an Andisol treated with different types of fertilizers. Environ. Pollut. 121(3), 477-487. DOI: dx.doi.org/10.1016.

33. Erhart, E., Feichtinger, F., \& Hartl, W. (2007). Nitrogen leaching losses under crops fertilized with biowaste compost compared with mineral fertilization. J. Plant Nutr. Soil Sci., 170(5), 608-614.

34. Czyżyk, F. \& Rajmund, A. (2011). Quantity of nitrogen deposited in soil as precipitated from atmosphere in the Wroclaw area during 2002-2007. Ecol. Chem. Engineering A 18(4), 515-521. 